\title{
Effects of Temperature and Water Purity on Germination and Yield of Mungbean Sprouts
}

(Kesan Suhu dan Ketulenan Air Bagi Percambahan dan Hasil Kecambah Mungbean)

\author{
MuHAmmad HANIF*, MansoOR KHAN KHATTAK, InAm Ul HaQ, KaUSAR Gul, \\ ANSA KHAN, KalEEM Ullah, Ali KHAN \& AZMAT Ali
}

\begin{abstract}
Mungbean (Vigna radiata L. Wilczek) is a popular pulse crop, producing protein-rich food and nitrogen-rich residues. Mungbean sprouts were grown at different temperature levels of 10, 20 and $30^{\circ} \mathrm{C}$ in various water purities of 30 (distilled water), 100, 400, 700 and 1000 TDS ( ppm). After keeping them in the germination chamber for $72 \mathrm{~h}$, the percentage of germination, stem length and yield along with proximate composition were determined. The temperature was kept as main factor and water purity as the second. The experiment was replicated four times and the data obtained were analyzed using two factorial completely randomized design. The results showed that both the factors had significant $(\mathrm{p} \leq 0.05)$ effect on the germination, stem length, yield as well as proximate composition. A temperature of $30^{\circ} \mathrm{C}$ and water with high purity of $30 \mathrm{TDS}$ resulted in high emergence (69\%), stem length $(3.14 \mathrm{~cm})$ and yield $(70.1 \mathrm{~g})$ as compared to the other treatments. Minimum germination $(2.1 \%)$, stem length $(0.11 \mathrm{~cm})$ and yield $(12.11 \mathrm{~g})$ were recorded in samples kept at low temperature of $10^{\circ} \mathrm{C}$ and water purity with $1000 \mathrm{TDS}$. The mungbean seeds showed a very low plasticity to water purity, and that they were very susceptible to water impurities. It is concluded that, to prepare sprouts from mungbeans, it is necessary to germinate mungbean seeds them in water having high purity and temperature of $30^{\circ} \mathrm{C}$ for maximum germination, stem length and yield.
\end{abstract}

Keywords: Germination; mungbeans; sprouts; stem length; yield

\section{ABSTRAK}

Mungbean(Vigna radiata L. Wilczek) ialah tanaman popular pulse, menghasilkan makanan kaya protein dan sisa yang kaya dengan nitrogen. Cambah Mungbean telah berkembang pada suhu yang berbeza iaitu 10, 20 dan $30^{\circ} \mathrm{C}$ dalam pelbagai ketulenan air 30 (air suling), 100, 400, 700 dan 1000 TDS (ppm). Selepas disimpan dalam bilik percambahan selama 72 jam, peratusan percambahan, panjang batang dan hasil komposisi proksimat telah dikenal pasti. Suhu penyimpan merupakan faktor utama manakala ketulenan air adalah faktor yang kedua. Uji kaji ini diulang kali sebanyak empat kali dan data yang diperoleh dianalisis menggunakan dua reka bentuk faktoran yang rawak. Keputusan menunjukkan bahawa kedua-dua faktor mempunyai kesan signifikan ( $\mathrm{p}<0.05)$ untuk percambahan, panjang batang, hasil serta komposisi proksimat. Suhu $30^{\circ} \mathrm{C}$ dan air dengan ketulenan yang tinggi 30 TDS menghasilkan kemunculan tinggi (69\%), panjang batang (3.14 cm) dan hasil (70.1 g) berbanding rawatan lain. Percambahan minimum (2.1\%), panjang batang (0.11 $\mathrm{cm})$ dan hasil $(12.11 \mathrm{~g})$ direkod dalam sampel yang disimpan pada suhu rendah $10^{\circ} \mathrm{C}$ dan ketulenan air dengan 1000 TDS. Benih mungbean menunjukkan keplastikan yang sangat rendah terhadap ketulenan air dan mudah terdedah kepada pencemaran air. Kesimpulannya, untuk mencambah benih mungbean, ia perlu dicambah di dalam air yang berketulenan tinggi serta suhu $30^{\circ} \mathrm{C}$ untuk percambahan, panjang batang dan hasil yang maksimum.

Kata kunci: Hasil; cambah; mungbean; panjang batang; percambahan

\section{INTRODUCTION}

Mungbean (Vigna radiata L. Wilczek), belonging to family Fabaceae, is a legume crop well-known in developing countries like India, Pakistan and Bangladesh. Being a rich and cheap source of proteins, mungbean is widely used as vegetable in developing world as it measure up to animal sources. The seeds have high nutritional value with high proteins, fibers, resistant starch and phytonutrients making them rich in antioxidants to reduce aging (Ronald et al. 2016). Mungbean is also used against chronic diseases like cancer, diabetes and cardiac diseases, and it is considered to be essential for myelination by oligodendrocytes within te brain (Chen et al. 2012).

Mungbean has been consumed in many forms like fried, boiled, powdered and sprouted. However, mungbean sprout is the most nutritious form as it contains $200 \%$ more protein as compared to other consumable forms. The nutritional value per $100 \mathrm{~g}$ of mungbean sprout is that it contains $7 \mathrm{~g}$ protein, $18 \mathrm{~g}$ carbohydrate, $24 \mathrm{~g}$ fat, $0.026 \mathrm{~g}$ sodium, $0.06 \mathrm{~g}$ potassium, $0.02 \mathrm{~g}$ iron, $0.029 \mathrm{~g}$ calcium, 103.5 calories of energy and other important vitamins (Hanumantha et al. 2016). 
One of the most important benefits of sprouting mungbeans is that it helps in the elimination of the anti-nutrient agent called phytic acid. Phytic acid is a well-known anti-nutrient that is present in other forms of mungbeans. This agent inhibits some of our important digestive enzymes that digest proteins and carbohydrates, including amylase, trypsin and pepsin. Thus sprouted mungbeans have higher digestibility as they are devoid of phytic acid. It also has increased absorption of vitamins, iron, zinc, magnesium and other minerals. Due to unique quality, mungbean sprouts are very famous and have high demand. However, sprouting requires certain specific conditions. The most important of which is favorable temperature in the range of $25-30^{\circ} \mathrm{C}$. Furthermore, it requires water free from any dilution and proper light (Islam et al. 2017).

Sprouts grow well in hot and humid weather, but the demand of sprouts increases in winter season when the condition is not favorable for sprouting. This increases demand of mungbean sprouts during winter and compels the hotels and suppliers to explore alternative ways of having fresh mungbean sprouts in winter. Although freezing or storage helps, it has the disadvantage of causing brownish discoloration in the sprouts. The growers try to grow sprouts in winter, but it fails to achieve the required yield and quality because mungbean seeds are sensitive to environmental condition. Special oven is nowadays also supplanted for this purpose, but the percent of sprouts emergence and yield is still very low (Maninder et al. 2017). The present study emphasizes on the impact of temperature and water purity on the percent of emergence and yield of mungbean sprouts.

\section{MATERIALS AND METHODS}

The study was conducted in food processing laboratory in the Department of Agricultural Mechanization, Faculty of Crop Production Sciences, University of Agriculture, Peshawar, Pakistan. Mature and high quality seeds of hybrid variety Golden (locally grown) were purchased. Some of these were tested for imbibition in favorable conditions $\left(30^{\circ} \mathrm{C}\right.$ in distilled water) to see if the seeds were alive. Golden variety was chosen as it is known to be the most protein containing mung bean variety in Pakistan. In addition, to ensure quality research, clean, uniformed and undamaged seeds were selected for the experiment.

\section{STERILIZATION OF THE SAMPLES}

All the seeds were soaked for $2 \mathrm{~min}$ in a $0.1 \%$ mercuric chloride solution to sterilize them. Then all the samples were put in Petri dishes containing different aqua solutions having different levels of purity ranging from 30 to 1000 TDS (total dissolved solids). Distilled water having 50 TDS was used as a control while four different solutions of $100,400,700$ and $1000 \pm 5$ TDS (ppm) were prepared for comparison. All the samples were tested three times with the electric conductivity meter (Water Filter Man, HM-S1, USA) to ensure accuracy. All the samples were put in germination chambers whose psychometric conditions were set according to the experiment. Each sample consisted of 100 seeds in a Petri dish replicated four times. All the samples were provided with $20 \mathrm{~mL}$ of the prepared solutions every $12 \mathrm{~h}$.

\section{PSYCHOMETRIC CONDITIONS OF THE GERMINATION CHAMBERS}

Three different setups were created in the germination chamber (PERCIVAL, 75ft3, USA) and the temperature was set at 20,30 and $40^{\circ} \mathrm{C}$ with a precision of $+1^{\circ} \mathrm{C}$ for separate experiments. The humidity remained in the ranges of $87.11-85.51 \%, 75.22-71.19 \%$ and $67.53-61.94 \%$ in the germination chamber during the experiment. All the samples were kept for $72 \mathrm{~h}$, and approximately $12 \mathrm{~h}$ of light (42000 Lux) was provided inside the chamber. These conditions are almost equal to the ones provided by the supplanted oven in the industries for sprouting.

\section{STATISTICAL ANALYSIS}

Experiments were laid out in completely randomized design with four replications. Temperature having three levels $\left(10,20\right.$ and $\left.30^{\circ} \mathrm{C}\right)$ was kept as first factor while water purity having five levels $(50,100,400,700,1000$ TDS) was kept as the second factor. Analysis of variance and statistical comparisons were made with $\mathrm{M}$ Stat $\mathrm{C}$ at 95\% confidence level (Gomez \& Gomez 1984). Data on germination (\%), sprout length $(\mathrm{cm})$ and sprout yield $(\mathrm{g})$ were recorded when mung bean achieved $90 \%$ visual germination (Figure 1).

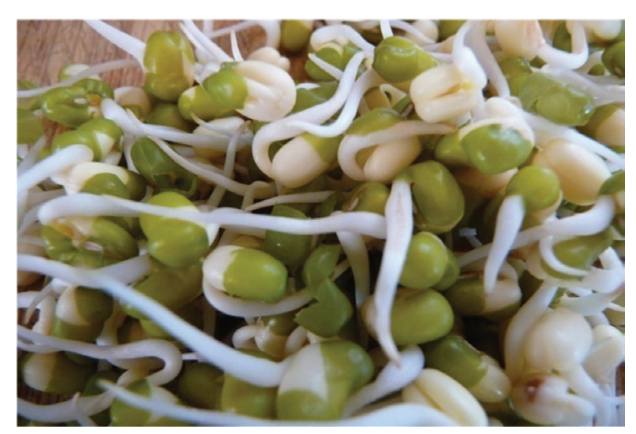

FIGURE 1. Sprouted mungbeans

\section{RESULTS AND DISCUSSION}

\section{EMERGENCE OF SEEDS TO SPROUT}

Percentage emergence of mungbean seeds, after the period of $72 \mathrm{~h}$ in the germination chamber, was recored (Figure 2 ). The statistical analysis of the data showed that both the temperature and water purity had significant $(p<0.05)$ effect on the percent of emergence of the mungbean seeds. When the temperature was kept constant, the germination percentage had a negative relationship with the water purity/TDS (Figure 2). $\mathrm{R}^{2}$ value of 0.927 showed $92 \%$ 


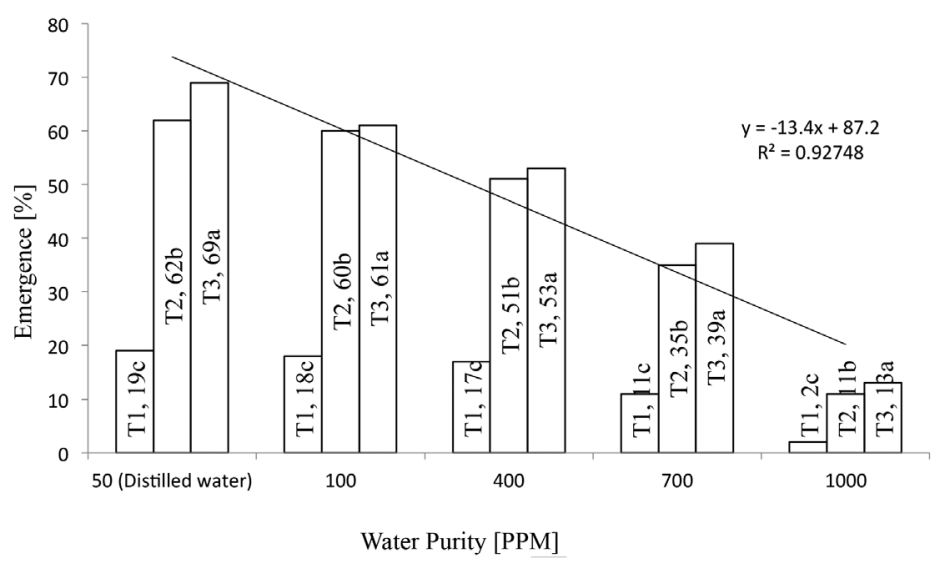

FIGURE 2. Emergence (\%) of mung bean seeds affected (Duncan's multiple range test at $p<0.05$ ) by different temperatures and water purity levels

of variation in percent of emergence due to the change in water purity/TDS. At 50 TDS and $40^{\circ} \mathrm{C}$, the percent of emergence was much higher (69\%) than all the treatments. On the other hand, the lowest percent of emergence (2\%) was found in the treatment having 1000 TDS at $10^{\circ} \mathrm{C}$. Khattak et al. (2007) stated that water purity is very necessary for mungbean seeds and lentil seeds to germinate properly. Decrease in purity of water will increase the TDS causing an adverse effect on the germination of mungbean seeds. Vinod and Reddy (2015) also reported the results in accordance with the findings of our experiments. They indicated that purified or distilled water without any impurity would increase germination percentage of mungbean seeds.

The means of emergence with the temperature levels showed a significant effect on the percent of emergence (Figure 3). Furthermore, percent of emergence of sprouts had a positive relationship with level of temperature. Penas et al. (2008) stated that the temperature range of $10-40^{\circ} \mathrm{C}$ had a positive relationship with the percent of emergence. Population growth of different pathogens also decreased with increase in temperature. This is due to the fact that at high temperature $\left(>30^{\circ} \mathrm{C}\right)$ the growth of microorganisms begins to decrease. Increasing temperature will control the growth of micro organisms.

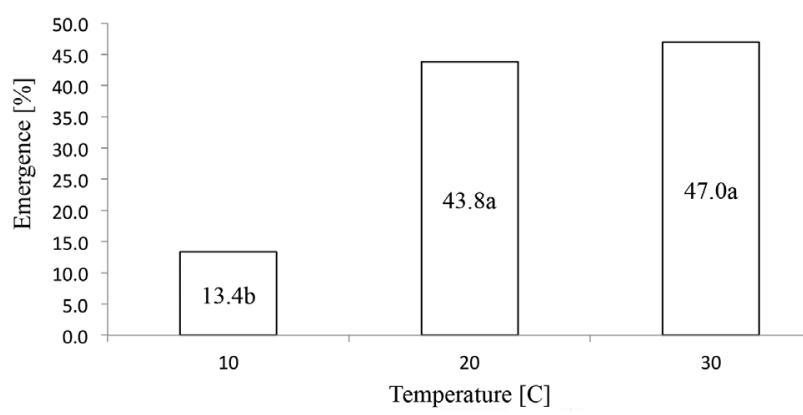

FIGURE 3. Means of emergence (\%) of mungbean seeds affected (Duncan's multiple range test at $p<0.05$ ) by different temperature levels
The means of emergence with the water purity level showed a significant effect on the percent of emergence (Figure 4). Percentage emergence of sprouts had a negative relationship with the water purity. This is due to the fact that as osmotic pressure increases with the increase in water TDS, it causes a change in the nutrient contents of the media or water quality significantly affecting the seed emergence as well as its growth. Vijay and Abhishek (2009) reported that water turbidity increases osmotic pressure outside the roots on mungbean which makes it difficult for the seeds to germinate. The same phenomena were recorded in this experiment. It may be possible that adequate amount of nutrient stores and the artificial media or solution exist for compensation of differing nutrient levels. However, availability of nutrients and seed reserves are not most favorable, and nutrient solutions positively responded to the seed emergence. Seedling emergence decreased with increase of TDS (Chen et al. 2012).

\section{STEM LENGTH OF SPROUTS}

The stem length of sprouts (Figure 5) showed a significant effect from different levels of temperature and water purity/ TDS. Stem length of sprouts was significantly affected by the water purity/TDS. There was a negative relationship between stem length and water purity/TDS. There was no obvious difference of stem length among the different treatments at early stages. By extending the time, the first treatment having 50 TDS showed faster growth at constant temperature. At $50 \mathrm{TDS}$ and temperature of $30^{\circ} \mathrm{C}$, the longest stem length was observed. However, by decreasing temperature the length of sprout stems declined. As a result, at $10^{\circ} \mathrm{C}$, the shortest stem length was recorded (Figure 5). At 1000 TDS, the shortest stem length among all the treatments was recorded.

The results showed that there was a positive relationship between temperature and stem length with an $\mathrm{R}^{2}$ value of 0.896 (Figure 6). The lowest stem length $(2.47 \mathrm{~cm})$ was found at a temperature of $10^{\circ} \mathrm{C}$. A slight difference $(0.22 \mathrm{~cm})$ was found between the stem length treated at 10 and $20^{\circ} \mathrm{C}$. The largest stem length $(3.14 \mathrm{~cm})$ 


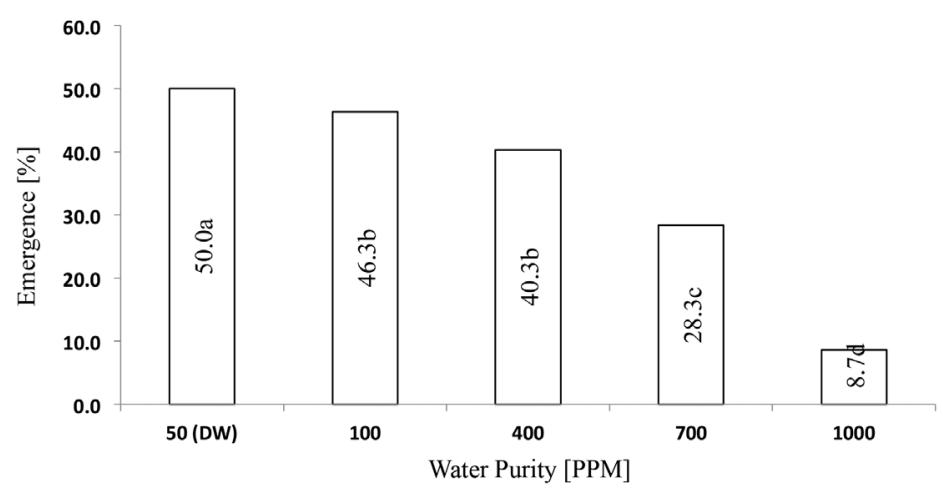

FIGURE 4. Means of emergence of mungbean seeds affected (Duncan's multiple range test at $p<0.05$ ) by different water purity levels

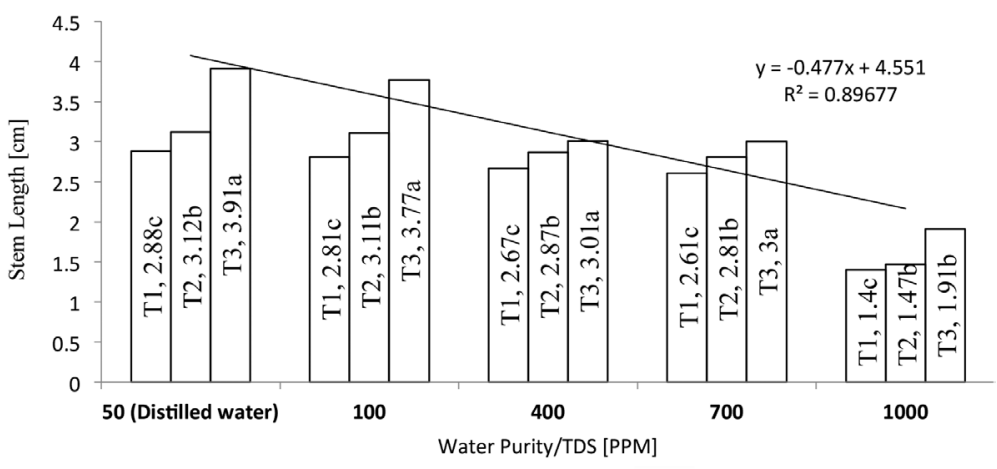

FIGURE 5. Stem length of mungbean seeds affected (Duncan's multiple range test at $p<0.05$ ) by different temperatures and water purity levels

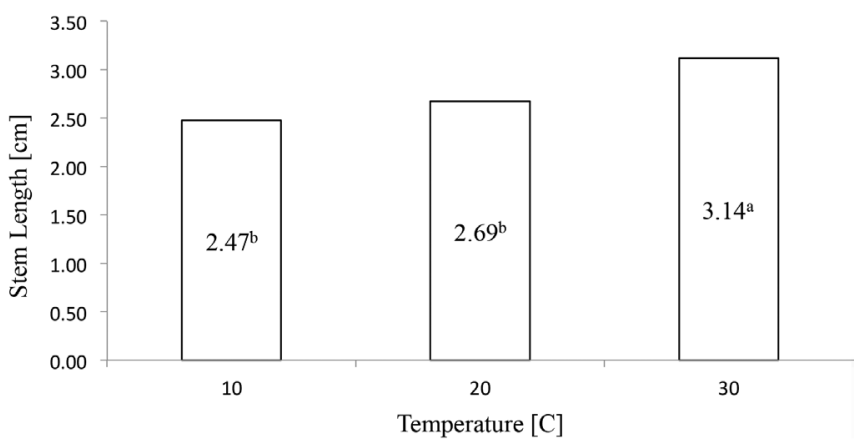

FIGURE 6. Means of stem length $(\mathrm{cm})$ of mungbean seeds affected (Duncan's multiple range test at $p<0.05$ ) by different temperature levels

was found at a temperature of $30^{\circ} \mathrm{C}$. Hence, it is concluded that stem length of sprouts was significantly affected by the temperature.

Panuccio et al. (2014) stated that the increase in the mineral contents in the solution or media decreased the development of sprout stem. Seed emergence, growth, development and survival depended on the type of media or solutions. The high amount of ions produced osmotic and ionic stresses. Osmotic stress occured in the root or radical while ionic stress developed when higher amount of unavoidable ions accumulated in the cells. These high amounts of ions affect the plant enzymes, resulted in reduced energy production and other physiological processes.

The results showed that there was a negative relationship between stem length and water purity/TDS with $\mathrm{R}^{2}$ of 0.88 (Figure 7$)$. The highest stem length $(3.12 \mathrm{~cm})$ was found at 50 TDS. 50 and 100 TDS were found highly significant while poor significance was found at 1000 TDS. There was a minor difference found between the stem length treated with 400 and 700 TDS. It is concluded that the stem length was significantly affected by the water purity/ TDS. Lal and Shanmugasundaram (2001) reported the same results in favour of our experiment that mungbean 
subjected to water with high impurity has a reduction in the stem length.

\section{YIELD OF SPROUTS}

The yield of mungbean sprouts was significantly affected by the treatments (Figure 8 ). The highest average yield $(70.14 \mathrm{~g})$ was found by applying $50 \mathrm{TDS}$ at $30^{\circ} \mathrm{C}$. A smaller difference $(1.03 \mathrm{~g})$ in yield of sprouts was found between 50 and $100 \mathrm{TDS}$ at $30^{\circ} \mathrm{C}$. All the lowest yields were found by applying 1000 TDS media. At 10,20 and $30^{\circ} \mathrm{C}$ the average yield recorded were 12.2, 34.4 and $40.98 \mathrm{~g}$, respectively. If the temperature was kept constant, the yield of sprouts would show a negative relationship with the water purity/ TDS.

The type of media or nutrients provided to plants or seeds showed a significant difference than that of control. Some type of nutrients accelerated the growth and yield of selected plants or seedlings while other inhibited the growth or declined the yield. Some nutrients increased or decreased the $\mathrm{pH}$ of the solution which led to the decrease in the yield of seedling and plant growth. The solution with $\mathrm{pH} 7$ showed a good response in increasing growth and yield of sprouts or seedling or even plant growth. There was a direct relationship between TDS and $\mathrm{pH}$ value in a solution. In the same way, the solution having high TDS showed decline growth and yield. It may be summarized that there was a negative relationship between TDS and growth or yield (Bouchard et al. 2007; Islam et al. 2017).

The results showed that there was a positive relationship between the yield of sprouts and temperature with an R2 value of 0.887 (Figure 9). The highest average yield $(58.96 \mathrm{~g})$ was found in the temperature treatment of $30^{\circ} \mathrm{C}$. The lowest average yield $(30.08 \mathrm{~g})$ was found in the temperature treatment of $10^{\circ} \mathrm{C}$. At $20^{\circ} \mathrm{C}$ the average yield was $50.73 \mathrm{~g}$. There was a small difference in the average yield between the treatments treated with 20 and $30^{\circ} \mathrm{C}$. It is concluded that the yield was significantly affected by the temperature.

The results showed that the yield of sprouts was significantly affected by the water purity (Figure 10). At 50 and 100 TDS, the yield of sprouts was $57.1 \mathrm{~g}$ and 56.4 $\mathrm{g}$, respectively. Both the treatments were highly significant in the production of mungbean sprouts. The average difference between these two treatments was $0.68 \mathrm{~g}$. The lowest yield (29.22 g) was found by applying $1000 \mathrm{TDS}$.

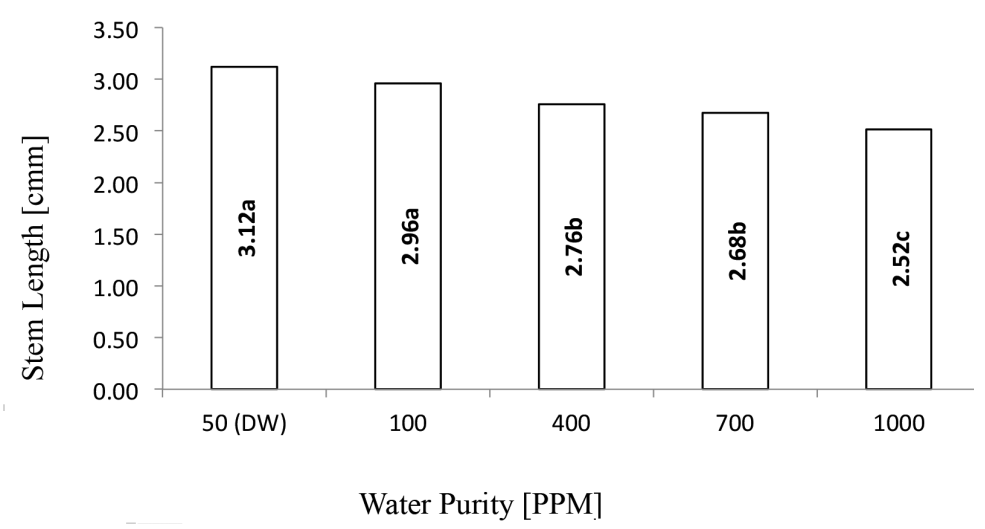

FIGURE 7. Means of stem length of mungbean seeds affected (Duncan's multiple range test at $p<0.05$ ) by different water purity levels

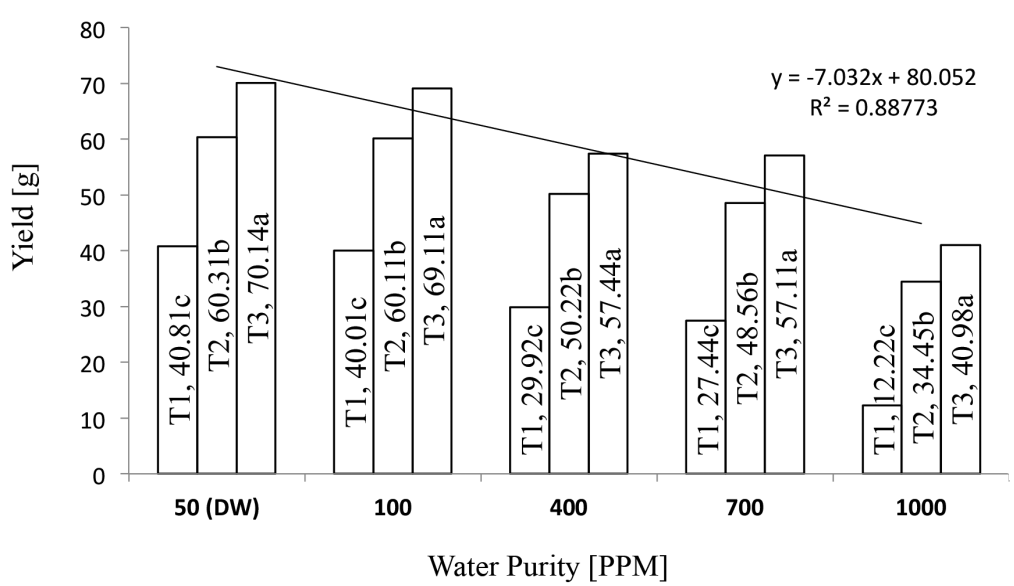

FIGURE 8. Yield of mungbean sprouts affected (Duncan's multiple range test at $p<0.05$ ) by different temperatures and water purity levels 


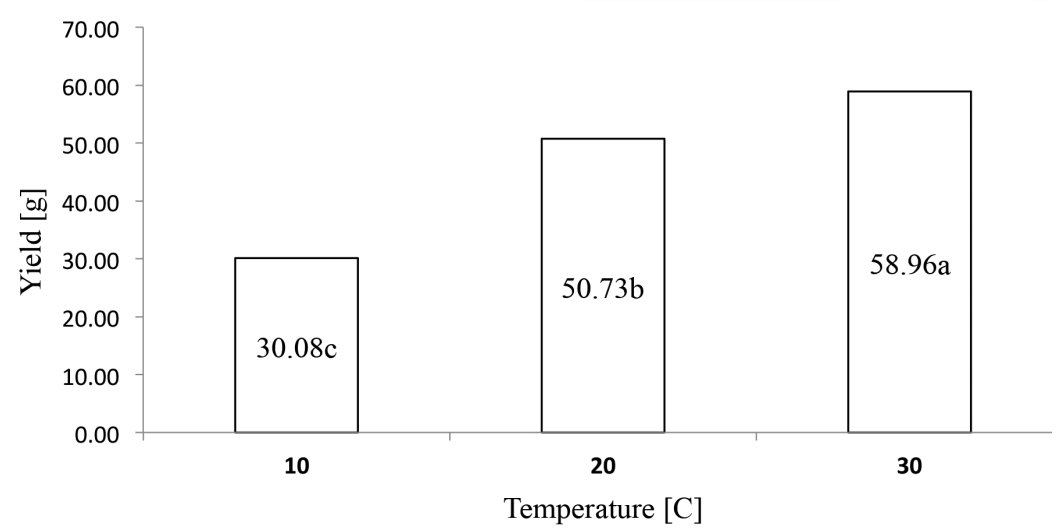

FIGURE 9. Means of yield of mungbean sprouts affected (Duncan's multiple range test at $p<0.05$ ) by different temperature levels

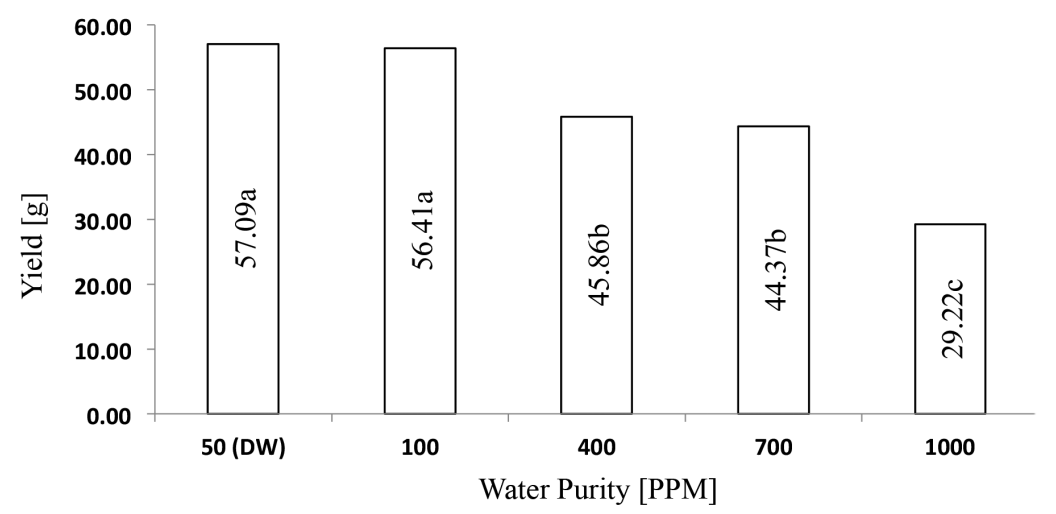

FIGURE 10. Means of yield of mungbean sprouts affected (Duncan's multiple range test at $p<0.05$ ) by different water purity levels

At 400 and 700 TDS, the average yields obtained were 45.9 and $44.4 \mathrm{~g}$, respectively. Figure 8 shows that there was a negative relationship between yield and water purity. The results are in accordance with the findings of Hanumantha et al. (2016), Lal and Shanmugasundaram (2001) and Vijay and Abhishek (2009), reporting decrease in yield of mungbean sprouts by the effect of water TDS.

\section{CONCLUSION}

The results showed that mungbean (Vigna radiata) germinates properly in clean or distilled water. Increase in water TDS will cause an adverse effect on mungbean to germinate and produce sprouts. Similarly, temperature also plays a vital role in germination and sprouting of mungbean. It is thus recommended to germinate mungbean at a temperature of $30^{\circ} \mathrm{C}$ with clean or distilled water having TDS less than $100 \mathrm{ppm}$ to get high quality mungbean sprout with high percent of emergence mungbean seeds.

\section{ACKNOWLEDGEMENTS}

The authors acknowledge the fund provision by Higher Education Commission and also the laboratory facilities provided by the University of Agriculture Peshawar Pakistan.

\section{REFERENCES}

Bouchard, N., Harmon, K., Markham, H. \& Vandefifer, S. 2007. Effect of Various Types of Water on the Growth of Radishes (Raphanus sativus). https://msu.edu/ vandefi2/Portfolio/ labreport.pdf.

Chen, Y.P., He, J.M. \& Li, R. 2012. Effects of magnetic fields pretreatment of mung bean seeds on sprout yield and quality. African Journal of Biotechnology 11: 8932-8937.

Gomez, K.A. \& Gomez, A.A. 1984. Statistical Procedures for Agricultural Research. 2nd ed. Singapore: John Wiley \& Sons.

Hanumantha, B., Nair, R.M. \& Nayyar, H. 2016. Salinity and high temperature tolerance in mungbean (Vigna radiata $\mathrm{L}$. Wilczek) from a physiological perspective. Frontiers of Plant Science 7: 957-964.

Islam, M.J., Hassan, M.K., Sarker, S.R., Rahman, A.B. \& Fakir, M.S.A. 2017. Light and temperature effects on sprout yield and its proximate composition and vitamin $\mathrm{C}$ content in lignosus and mung beans. Journal of Bangladesh Agricultural University 15: 248-254.

Khattak, A.B., Alamzeb, A., Maazullah, K., Nizakat, B., Ihsanullah. \& Khattak, M.S. 2007. Influence of germination 
techniques on sprout yield, biosynthesis of ascorbic acid and cooking ability in chickpea (Cicer arietinum L.). Food Chemistry 103: 115-120.

Lal, G. \& Shanmugasundaram, S. 2001. Mungbean Sprout Production. Training Manual. Asian Vegetable Research and Development Center, Shanhua, Taiwan.

Maninder, M., Kamboj, U., Sharma, A., Guha, P. \& Mishra, S. 2017. Green method for determination of phenolic compounds in mung bean (Vigna radiate $\mathrm{L}$.) based on nearinfrared spectroscopy and chemometrics. International Journal of Food Science and Technology 51: 2520-2527.

Panuccio, M.R., Jacobsen, S.E., Akhtar, S.S. \& Muscolo, A. 2014. Effect of saline water on seed germination and early seedling growth of the halophyte quinoa. AoB Plants 6: 47-51.

Penas, E., Gomez, R., Fariaz, J. \& Velverde, V.C. 2008. Application of high pressure treatment on Alfalfa and mungbean seeds to enhance microbiological safety of their sprouts. Food Control 19: 698-705.

Roland, S., Ramakrishnan, N., Khan, S., Kuziev, B., Schreinemachers, P., Hilger, T. \& Solberg, S.O. 2016. Beans With Benefits: Integrating Improved Mungbean as a Catch Crop into the Dryland Systems of South and Central Asia. 20th EUCARPIA General Congress, Zurich, Switzerland.
Vijay, L.K. \& Abhishek, S. 2009. Germinating seeds of the mung bean, Vigna radiata (Fabaceae), as a model for the preliminary evaluation of cytotoxic effects of drugs. Biocell 33: 19-24.

Vinod, J.D.K. \& Reddy, A.S. 2015. Genetic variation of phytic acid content in mungbean (Vigna radiata $\mathrm{L}$. Wilczek). The Crop Journal 3: 157-162.

Department of Agricultural Mechanization

The University of Agriculture Peshawar

Pakistan

*Corresponding author; email: hanif_mechanization@aup.edu.pk

Received: 3 May 2018

Accepted: 14 January 2019 